\title{
Linking organisational training and development practices with new forms of career structure: a cross-national exploration
}

\author{
Aidan Kelly \\ Department of Business Administration, Smurfit School of Business, \\ University College Dublin, Ireland \\ Teresa Brannick \\ Business Research Programme, University College Dublin, \\ Smurfit School of Business, Dublin, Ireland \\ John Hulpke \\ Hong Kong University of Science and Technology, Hong Kong \\ Jacqueline Levine \\ Department of Business Administration, Smurfit School of Business, \\ University College Dublin, Ireland \\ Michelle To \\ Department of Management of Organizations, \\ The Hong Kong University of Science and Technology, Hong Kong
}

\section{Keywords \\ Career development, Vocational training. \\ Human resource management}

\begin{abstract}
This paper reports the results of an empirical study which explores the extent to which career structures have changed. The study examines the influence of technological change, fastchanging environments, manufacturing and increasing globalisation of products and service markets on careers. The study focuses on these issues in a cross-cultural context. The study found that in general, more sophistic ated human resources activities were associated with career pathing in organizations.
\end{abstract}

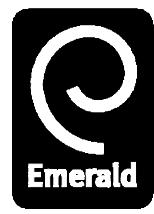

Journal of European Industrial Training

27/2/3/4 [2003] 160-168

(C) MCB UP Limited

[ISSN 0309-0590]

[DOI 10.1108/03090590310468985]

\section{Introduction and background}

During the 1990s the literature on careers grew exponentially. And while some say the end is in sight for "careers", there is not yet any end in sight for the debate. Much of this literature reflects the growing debate on the nature of work and the career in an unprecedented fast-changing environment, embracing new information, manufacturing and process technologies in the context of the increasing globalisation of product and service markets. A central theme in this field has focused on whether the concept of the career is really undergoing fundamental change as a result of this environmental turbulence, or indeed, if in practice very little is really changing. Some argue that changes have occurred and that the demise of the traditional career is inevitable; they see organizations and individuals abandoning the traditional organizational framework, within which stable, long-term career planning was feasible (Cappelli, 1999, 2000). Others, however, surmise that the career is merely adapting to changing economic conditions and that no fundamental change is evident (Jacoby, 1999a, b). Others suggest that the changes taking place may be random, rather than indicative of a new patterned stability, or, indeed, that the orderly form of career that has existed during the past 50 years or so has itself been the aberration (Collin and Young, 1986)

Clearly, there is ample evidence to show that economic constraints, more intense competition, increasing globalisation and other factors have brought dramatic changes to organization structures (Brousseau et al., 1996). Brousseau et al. argued that development, brought about by a rapidly changing business environment, concerns the change in the nature of careers. Our traditional understanding of the career as being a series of upward moves, with increasing income, status, power and security within a single organisation, is being challenged (Jacoby, 1999; Osterman, 1996; Allred et al., 1996). Career management systems have traditionally been perceived as being paternalistic, centralised, and top-down with only one kind of mobility having recognised value for most job ladders - vertical movement through the hierarchy (Nicholson, 1996). It is argued that the consequences of dramatic downsizing, delayering and other factors are creating considerable instability, uncertainty and insecurity for traditional career structures (Baruch, 1999). Such vacillation and unpredictability, it is argued, is likely to have a debilitating effect on the traditional concept of the secure and stable career. The key question is whether or not the career is "dead" as a result of our chaotic environment, as Cappelli (2000) prophesises, or is the career merely evolving and adapting and simply seeming to present a transformation of appearance, an outcome proposed by Jacoby (1999a, b). If career patterns are changing then there would be an expected follow through in organizational training and development practices.

Those who propose a new era of careers maintain that the order and predictability associated with the traditional career has 
Aidan Kelly,

Teresa Brannick, John Hulpke,

Jacqueline Levine and

Michelle To

Linking organisational training

and development practices

with new forms of career

structure: a cross-national

exploration

Journal of European Industrial

Training

27/2/3/4 [2003] 160-168 decreased (Cappelli, 2000; Collin and Young, 1986). They maintain that lateral and horizontal movement has become more common-place and a wider variety of alternatives exist in place of traditional routes (Rousseau, 1998; Hall, 1996; Arthur and Rousseau, 1996a, b). Lateral cross-functional moves, job switches, downward moves, and temporary moves are examples of such alternative career movement. Traditionally, individuals followed a career path that stayed within one function only and the recognized route was primarily vertical. It was not common to deviate from this norm. Items relating to movement across functions, and from technical to specialist roles or positions, and also through or across hierarchical levels may also be seen as indicators of the existence of alternative types of career paths, or those that deviate from traditional norms.

New ways of thinking about careers suggest that the career is not a universal concept, a social phenomenon, individual, or traditionally developmental (Collin and Young, 1986). On the contrary, it is argued that the career is a social construct. It is protean, contextual and relational (Collin and Young, 1986). A failing of traditional career theory is that it has a lack of utility to particular segments of the population through its neglect of the complexities of structural and cultural factors (Collin and Young, 1986). Career components such as hierarchy, centralisation or decentralisation, empowerment, and autonomy should vary across cultures. Certain cultures may be considered to be more conducive to self-management and empowerment, flexible working arrangements, and inter-organisational mobility, while others are likely to be more hierarchical, autocratic, and dominated by more centralised management and organisational structures. This study is concerned with offering empirical evidence concerning cross-cultural variations in career systems. In particular it will probe the extent to which emerging career structures are influenced by varying cultural circumstances. In addition, it will investigate the relationship between career management practices and training and development.

This discussion about the permanence or disappearance of careers has in large part taken place with little or no reference to location. But if "turbulence" is a factor contributing to the death of the career concept, should economies with more turbulence see ideas of careers fading faster? In most of the literature to date, the assumption seems to be that careers take place in Western settings. With few exceptions (see Brown, 2002; Chow, 1995; Granrose, 1995; Kao et al., 1997; Peng, 1995), the articles published have been written by and describe situations in Europe or North America. Thus when we designed the present study, we purposely studied more than one economic setting. Data were obtained from Shanghai, Hong Kong, Singapore, and Ireland. Hong Kong and Singapore both share Chinese culture. In addition, Hong Kong has since 1997 been a special administrative region of the People's Republic of China. Both Hong Kong and Singapore have since 1997 seen less than booming economic conditions. In China we collected data from Shanghai, a city whose economy is the subject of world-wide envy. As a 2002 article published in Taiwan put it:

Shanghai ... is too big an opportunity to pass up .... In the first three quarters of this year [2001] the city grew by $12.5 \% \ldots$

Headhunter numbers are showing a steady increase in Shanghai and don't seem to be slowing yet ....

Shanghai is about more than just the numbers however. ... There is a kind of vibrant energy associated with Shanghai now ... (Lawrence, 2002)

Data were also collected from Ireland, the "Celtic Tiger" economy has been one of Europe's pleasant surprises of the late twientieth century. Thus information was collected from Hong Kong and Singapore, Asian societies with Chinese culture but less than exuberant economic conditions, an economically booming Chinese city, Shanghai, and from Ireland in Europe. The key question for this paper is still about the future of careers. Primarily, by studying the issue cross-culturally and in economies of varying levels of performance, the study hoped to gain hints of connections which may or may not merit further examination later.

\section{New career structures}

Those who support the new order of careers have formulated various models to represent what they see as the new reality. Such models focus on the dissolution of boundaries, the emergence of employee self-management and the accumulation of marketable skills (Arthur and Rousseau, 1996a, b; Hall, 1996; Handy, 1997; Peiperl and Baruch, 1997). Drivers for change have impacted on organizations in various ways. Due to organizational restructuring, increasing level of inter-firm mobility, and the emergence of a core-periphery workforce, 
Aidan Kelly,

Teresa Brannick, John Hulpke,

Jacqueline Levine and

Michelle To

Linking organisational training and development practices

with new forms of career

structure: a cross-national

exploration

Journal of European Industrial

Training

27/2/3/4 [2003] 160-168 organizational boundaries are dissolving and

becoming less defined (Mallon, 1999a, b; Osterman, 2000). Arthur and Rousseau (1996) propose a new employment principle for this new age - the "boundaryless career". "Boundaryless" distinguishes the old from the new - the "bounded", or traditional organizational career, viewed people in orderly employment arrangements achieved through vertical co-ordination in mainly large, stable firms (Arthur and Rousseau, 1996a, b); the dissolution of these boundaries, it is argued, transforms the traditional career environment.

The new boundaryless environment requires many alternative visions with regard to the future of career concepts. Watts (1996) maintains that a career describes "an individual's life-time progression in learning and work". His use of the word progression is significant; instead of being constrained by hierarchical promotion, progression in learning and in work can take place through lateral and horizontal as well as vertical movement. It can occur within positions and it can also be affected by outside organizational structures (Watts, 1996). Conventionally, career paths were bounded by organizational structures and the accepted route was primarily vertical. Currently, human resource practices such as planned job rotation, dual ladders and multiple career paths have resulted in a greater variety of career options. Movement across functions, and from technical to specialist roles or positions, and also through or across hierarchical levels have also contributed to and/or are indicative of the breakdown of organizational boundaries both internal and external.

Peiperl and Baruch (1997), who coined the termed "post corporate career", concede that "big company" or main-stream careers still exist, but they are no longer the main routes to success. They see emerging careers as taking place outside the organization. They note that individuals pursuing such careers often act as vendors of skills to the very organization they have transcended (Quinn, 1999). Post-corporate careerists are independent and flexible, making their own choices and decisions. Another characteristic of individuals who are following a post corporate career path is that they have ceased to identify with a particular organization. They now identify with their chosen profession or industry. Thus, there appears to be a shift from an organizational focus to a self-focus.

Advocates of the "protean" (Hall, 1996) and "portfolio" (Handy, 1997) career models also perceive a move from paternalism in organizations to self-management on the part of the employee (Manz et al., 1990). These models suggest an accumulation of marketable skills by the individual to add to his/her variety of work experiences and independence (Mallon, 1999b). If such models are becoming a reality then there will be considerably more generalists in the workplace with more exposure to a variety of functional experiences (Kimeldorf, 1996; Mallon, 1999b). These models suggest more movement inside and outside the organization, a more independent careerist and alternative routes to success.

The new career models seem to possess several common elements. Some authors have described the new employment contract as one in which individuals take responsibility for managing their own careers, where mobility across organizations is extensive, where boundaries have dissolved and security has changed form (Mallon, 1999a, b; Templer and Cawsey, 1999). However, many employers are interpreting the new contract as meaning that employees should be completely responsible for their careers and that the employer bears little or no responsibility (Cappelli, 2000; Mallon, 1999a; Templer and Cawsey, 1999). This line of thinking views employees, even core employees, as being in a free agent role, similar to contract workers. At the same time, many organizations see their responsibility as providing opportunities for continuous learning, which will result in the creation of employability (Collin and Young, 1986).

\section{Implications for training and development}

Undoubtedly, changing economic and organizational structural circumstances have a strong impact on human resource management, particularly on career planning and management (CPM) systems (Baruch, 1999). Human resource managers face the challenge of managing people in an increasingly volatile business environment. CPM practices need to incorporate the changing reality of careers, reflecting emerging organizational structures and changing environmental situations. This new environment will demand a re-thinking of training and development practices. Rousseau and Arthur (1999) agree that there is a need for a new type of HR function in this emerging economic era. A more collaborative, symbiotic relationship between workers and organizations may be in order (Von Hippel et al., 1997). HR is 
Aidan Kelly,

Teresa Brannick, John Hulpke, Jacqueline Levine and

Michelle To

Linking organisational training and development practices

with new forms of career

structure: a cross-national

exploration

Journal of European Industrial

Training

27/2/3/4 [2003] 160-168 simultaneously attempting to position firms and employees to respond flexibly to market changes, while seeking stability by recruiting, developing and retaining people whose talents are critical to the firm (Rousseau and Arthur, 1999). Thus, we see an emerging paradox in career management structures, as Rousseau and Arthur (1999) put it, to cope with the "twin pressures for flexibility and stability". An example of the above may be observed when organizations dedicate their resources to the development of specific individuals rather than to their workforce as a whole. It has also been argued that these new career structures place much more emphasis on individuals managing their own training and development, with a strong emphasis on personal development. Therefore training in organizations may be more informal than it would be in more traditional organizations. Much of the literature also suggests a move towards a more generalized focus of training. For example, Ashkenas et al. (2002) note that in traditional hierarchical organizations, senior employees receive strategic education whereas lower level employees only receive skills training. However, in newer "boundaryless" organizations, all employees receive similar strategic education regardless of their level. Such practices may be indicative of a newer type of human resource practice.

\section{The current research study}

The extensive literature on career structures, while containing substantial evidence on a wide range of issues of concern to individuals, has failed to address matters of concern at the organizational level. In particular, there is no substantive cross-national study at the organizational level as to what may be happening to career structures in environments that are both culturally and structurally different.

This paper is a preliminary investigation of career structures and their implication for training and development practices in four different environments - Hong Kong, Singapore, mainland China (Shanghai) and Ireland. These four country regions contain certain cultural and business environment similarities, but also represent significant differences in these dimensions. The objective of this research is to examine the effects of cultural differences on the ways in which organizations manage careers and training related issues. It investigates whether there are differences between locations in relation to key career variables, such as the types of career paths, training and development practices and the inter relationships between career variables and training and development factors.

\section{Research methodology}

Following several preliminary interviews with human resource managers in China (Shanghai), Hong Kong and Ireland a questionnaire was developed and surveys of career dimensions in organizations in the various countries were conducted. As stated, the principal unit of analysis is the organisation, and postgraduate programme participants in the various participating institutions are the organisational conduits. The participating institutions in the study are:

- the Graduate School of Business, University College Dublin

- the Hong Kong University of Science and Technology;

- the China-Europe International Business School (CEIBS), Shanghai;

- the Cyprus International Institute of Management; and

- the Asia Pacific Management Centre (Singapore and Hong Kong).

The present paper contains an analysis of almost 590 organisations - 149 in Ireland, 201 in Hong Kong, 92 in Singapore and 144 in mainland China.

There is a significant relationship between country of location and size and sector, Ireland, Hong Kong and China having very similar size profiles with about 30 per cent in the 1,000 plus category (see Table I). Surprisingly, Ireland has the lowest percentage, 13 per cent, of small firms with less than 50 employees and the largest percentage, 34 per cent, in large firms employing 1,000-plus employees. The Singapore sample comprises small companies, with 30 per cent employing 50 or less workers. In relation to sector, China is dominated by manufacturing, while financial services is the biggest category in Hong Kong and traditional services is big in Singapore (see Table II).

\section{Results, analysis and discussion}

The findings indicate that the locations studied show distinctively different patterns in certain key career dimensions. Overall it appears that Hong Kong has the most traditional careers patterns, Singapore and Ireland have the least traditional career and mainland China presents a dual picture. 
Aidan Kelly,

Teresa Brannick, John Hulpke,

Jacqueline Levine and

Michelle To

Linking organisational training

and development practices

with new forms of career

structure: a cross-national

exploration

Journal of European Industrial

Training

$27 / 2 / 3 / 4$ [2003] 160-168

\section{$\overline{\text { Table I }}$}

Number of full time employees by country of location*

\begin{tabular}{|c|c|c|c|c|}
\hline & $\begin{array}{c}\text { Ireland } \\
(\%)\end{array}$ & $\begin{array}{c}\text { Hong Kong } \\
(\%)\end{array}$ & $\begin{array}{c}\text { Singapore } \\
(\%)\end{array}$ & $\begin{array}{c}\text { Mainland China } \\
(\%)\end{array}$ \\
\hline \multicolumn{5}{|c|}{ Number of full time employees } \\
\hline$<50$ & 13 & 19 & 30 & 15 \\
\hline $50-100$ & 11 & 14 & 16 & 12 \\
\hline $101-500$ & 27 & 22 & 25 & 29 \\
\hline $501-1,000$ & 13 & 11 & 7 & 14 \\
\hline$>1,000$ & 36 & 34 & 22 & 31 \\
\hline
\end{tabular}

Table II

Modern versus traditional class by country of location

\begin{tabular}{|c|c|c|c|c|c|c|c|c|c|c|}
\hline & \multicolumn{2}{|c|}{ Ireland } & \multicolumn{2}{|c|}{ Hong Kong } & \multicolumn{2}{|c|}{ Singapore } & \multicolumn{2}{|c|}{$\begin{array}{c}\text { Mainland } \\
\text { China }\end{array}$} & \multicolumn{2}{|c|}{ Total } \\
\hline & $n$ & $\%$ & $n$ & $\%$ & $n$ & $\%$ & $n$ & $\%$ & $n$ & $\%$ \\
\hline $\begin{array}{l}\text { Traditional manufacturing } \\
\text { Food technology } \\
\text { Mechanical }\end{array}$ & 18 & 13.2 & 23 & 12.5 & 7 & 8.0 & 31 & 23.0 & 79 & 14.6 \\
\hline $\begin{array}{l}\text { Modern manufacturing } \\
\text { Software } \\
\text { Electronic pharmaceutic } \\
\text { Health }\end{array}$ & 37 & 27.2 & 49 & 26.6 & 23 & 26.4 & 43 & 31.9 & 152 & 28.0 \\
\hline $\begin{array}{l}\text { Traditional services } \\
\quad \text { Retail } \\
\text { Hospital }\end{array}$ & 14 & 10.3 & 24 & 13.0 & 20 & 23.0 & 17 & 12.6 & & 75 \\
\hline $\begin{array}{l}\text { Modern services } \\
\text { Banking } \\
\text { Consulting } \\
\text { Accounting }\end{array}$ & 33 & 24.3 & 58 & 31.5 & 16 & 18.4 & 19 & 14.1 & 126 & 23.2 \\
\hline Other & 34 & 25.0 & 30 & 16.3 & 21 & 24.1 & 25 & 18.5 & 110 & 20.3 \\
\hline Total & 136 & 100 & 184 & 100 & 87 & 100 & 135 & 100 & 542 & 100 \\
\hline
\end{tabular}

There are several distinct differences, both at the organizational and individual career level (see Table III).

\subsection{Types of career paths}

Irish organizations are reported (36 per cent) as more likely than the Asian organizations sampled to have multiple career paths. Hong Kong organizations represented in this survey are much more likely to have within function career paths only (48 per cent) and promotion primarily vertical (48 per cent).

On the other hand, it is also clear that career paths within Irish organizations are largely a mixture of within function and cross-function paths. Singapore has low percentages on within function career paths and vertical promotion and the highest percentage, 14 per cent, for planned job rotation.

\subsubsection{The extent of career pathing}

This item is taken as a measure of traditional careers. High levels of career pathing within an organization imply that the organization is controlling and managing the individual's career. In organizations where newer models of careers are in use, more autonomy and self-management on the part of the employee is expected (Mallon, 1999a, b). There is some confusion inbuilt into this concept of "career pathing" as existing human resource thinking on career management practice would conceptualise low levels of career pathing as indicative of poor human resource practices in organizations. However, more recent literature relating to careers would indicate that lower levels of career pathing are indicative of the existence of newer models of careers. One issue of concern here is whether these findings are indicative of a new model of careers, or whether they are symptomatic of bad practice, or how the new career distinguishes itself from traditional “"poor” human resource management. The reported extent of career pathing in organizations in Ireland is significantly 
Aidan Kelly,

Teresa Brannick, John Hulpke,

Jacqueline Levine and

Michelle To

Linking organisational training and development practices

with new forms of career

structure: a cross-national

exploration

Journal of European Industrial

Training

27/2/3/4 [2003] 160-168

\section{Table III}

Career patterns by country of Iocation

\begin{tabular}{|c|c|c|c|c|}
\hline & Ireland & Hong Kong & Singapore & Mainland China \\
\hline \multicolumn{5}{|l|}{ Types of career paths } \\
\hline Career paths within function only (\% yes)*** & 22 & 48 & 29 & 35 \\
\hline Primarily vertical (\% yes) * * & 36 & 48 & 37 & 33 \\
\hline Initially vertical (\% yes) * * & 25 & 22 & 21 & 35 \\
\hline Planned job rotation ( $\%$ yes) & 7 & 8 & 14 & 9 \\
\hline Dual ladder ( $\%$ yes) & 19 & 14 & 19 & 13 \\
\hline Multiple (\% yes) ${ }^{*} *$ & 36 & 20 & 22 & 23 \\
\hline \multicolumn{5}{|l|}{ The existence of career pathing } \\
\hline (high score defined paths) (average score ${ }^{* *}$ ) & 4.7 & 6.0 & 5.3 & 5.8 \\
\hline \multicolumn{5}{|l|}{ Career development } \\
\hline \multicolumn{5}{|c|}{ Organization grows and develops skills in their employees } \\
\hline (\% yes) & 73 & 62 & 62 & 74 \\
\hline \multicolumn{5}{|l|}{ Organizational resources are allocated to fast trackers } \\
\hline only $(\% \text { yes })^{* * *}$ & 27 & 51 & 42 & 50 \\
\hline
\end{tabular}

lower than that reported in Hong Kong, Singapore and mainland China. The highest score is reported by Hong Kong.

\subsubsection{Organizational resources are allocated to fast trackers only}

This item is taken as a proxy indicator of the use of more traditional career paths. Those organizations that take responsibility for fast trackers only rather than all employees are exercising a style of management indicative of traditional career management programs. Again, Hong Kong pointed towards a more conventional style of management. A total of 51 per cent of respondents from Hong Kong indicated that resources were allocated to fast trackers only. Like Hong Kong, China also seemed to show a traditional management style here, with 50 per cent of respondents reporting that resources in their companies were allocated to fast trackers only. However, just 27 per cent of Irish respondents stated that this was the case. These findings indicate that what is generally accepted as best modern HRM practice, perhaps from a Western perspective, is more evident in Irish organizations. Ireland and mainland China report the higher percentage, over 73 per cent, in relation to organizations growing and developing skills in their employees.

In summary, of the four locations studied, Hong Kong seems to have more traditional management styles in place than the others. Ireland and Singapore seem to show the most evidence of newer career structures. Mainland China, on the other hand, presents a dual picture. In some cases China seems similar to Hong Kong, yet in other ways it resembles Ireland and Singapore more closely.

\subsection{Training and development practices} Distinct differences were found between countries with regard to the provision of training and development. Irish companies reported the lowest number of training days for both technical and managerial employees. In Ireland only 22 per cent of organizations sampled reported that the organization took sole responsibility for training and development, whereas in Hong Kong and Singapore 37 per cent and 32 per cent respectively reported that the organization took the main responsibility for training and development. In mainland China this figure rose to 49 per cent (see Table IV). This would suggest that in Irish organizations employees are provided with training and development from a wider variety of sources than the organizations sampled in Asia. This may lend some credence to the argument that the "newer" forms of career are more evident in Ireland than in Asian countries.

\subsection{Link between career pathing and training and development practices} Paired sample correlations were carried out to examine the relationship between career pathing and a number of training variables (Table V). These variables included days spent training by managerial and also technical/skilled staff, focus of training (generalized or specialized) and formality of training. The analysis yielded some interesting findings. Irish companies presented the strongest links between training practices and career pathing.

The significant relationship between career pathing and formality of training was the only relationship to hold in the four country locations. The higher the level of career pathing, the more formal the available 
Aidan Kelly,

Teresa Brannick, John Hulpke,

Jacqueline Levine and

Michelle To

Linking organisational training

and development practices

with new forms of career

structure: a cross-national

exploration

Journal of European Industrial

Training

27/2/3/4 [2003] 160-168

\section{Table IV}

Training and development practices by country of location

\begin{tabular}{|c|c|c|c|c|}
\hline & $\begin{array}{l}\text { Ireland } \\
\text { (\% yes) }\end{array}$ & $\begin{array}{c}\text { Hong Kong } \\
\text { (\% yes) }\end{array}$ & $\begin{array}{c}\text { Singapore } \\
\text { (\% yes) }\end{array}$ & $\begin{array}{c}\text { China } \\
\text { (\% yes) }\end{array}$ \\
\hline \multicolumn{5}{|l|}{ Formality of training } \\
\hline Formal & 38 & 39 & 42 & 46 \\
\hline Informal & 36 & 39 & 31 & 32 \\
\hline Neither formal or informal & 26 & 23 & 27 & 23 \\
\hline \multicolumn{5}{|l|}{ Focus of training } \\
\hline Generalized & 29 & 32 & 36 & 41 \\
\hline Specialized & 48 & 44 & 35 & 38 \\
\hline Neither generalized or specialized & 23 & 24 & 30 & 21 \\
\hline \multicolumn{5}{|l|}{ Training days } \\
\hline \multicolumn{5}{|l|}{ Days spent in training, technical and skilled employees } \\
\hline (average days*) & 8.8 & 12.4 & 13.3 & 14.0 \\
\hline Days spent in training, managerial staff (average days*) & 8.6 & 10.0 & 13.0 & 13.5 \\
\hline \multicolumn{5}{|l|}{ Providers of training and development course? * } \\
\hline Organisation & 22 & 37 & 32 & 49 \\
\hline External vendors & 16 & 15 & 24 & 12 \\
\hline Employees' responsibility & 9 & 21 & 13 & 10 \\
\hline All of the above & 22 & 12 & 13 & 5 \\
\hline Organisation and external vendors & 24 & 8 & 11 & 14 \\
\hline External vendors and employee or organisation and workers & 6 & 2 & 1 & 4 \\
\hline
\end{tabular}

\section{$\overline{\text { Table V }}$}

Paired correlations - career pathing with a number of training variables by country of location

\begin{tabular}{|c|c|c|c|c|c|c|c|c|c|c|c|}
\hline & \multicolumn{2}{|l|}{ Ireland } & \multicolumn{3}{|c|}{ Hong Kong } & \multicolumn{3}{|c|}{ Singapore } & \multicolumn{3}{|c|}{ Mainland China } \\
\hline$n$ & $r$ & Sig. & $n$ & $r$ & Sig. & $n$ & $r$ & Sig. & $n$ & $r$ & Sig. \\
\hline \multicolumn{12}{|c|}{ Days spent in training by managerial staff and the extent of the existence of career pathing } \\
\hline 12 & 0.135 & 0.126 & 186 & 0.056 & 0.445 & 76 & -0.021 & 0.858 & 135 & 0.098 & 0.259 \\
\hline \multicolumn{12}{|c|}{ Days spent in training by technical/skilled staff and the extent of the existence of career pathing } \\
\hline$\cdot$ & 0.224 & 0.011 & 184 & 0.093 & 0.208 & 76 & 0.153 & 0.188 & 131 & 0.102 & 0.245 \\
\hline \multicolumn{12}{|c|}{ Level of generalization or specialization of training and the extent of the existence of career pathing } \\
\hline 14 & 0.235 & 0.005 & 196 & 0.062 & 0.390 & 86 & 0.231 & 0.032 & 143 & 0.118 & 0.162 \\
\hline \multicolumn{12}{|c|}{ Level of formality of training and the extent of the existence of career pathing } \\
\hline 14 & 0.489 & 0.000 & 197 & 0.317 & 0.000 & 87 & 0.494 & 0.000 & 142 & 0.374 & 0.000 \\
\hline
\end{tabular}

training. In Ireland, two other significant positive relationships were found between the existence of career pathing with days spent training by technical/skilled staff, level of specialization or generalization and formality of training. In other words, the higher the extent of career pathing, the higher the number of days spent in training by skilled/technical staff and the higher the level of formal training. Focus of training tended to be more generalized the higher the extent of existence of career pathing.

In Singapore, one additional training variable was significantly related to career pathing, that is the specialization/ generalization of training. However, this scenario is not indicative of the situation in Hong Kong and China, which yielded similar results with only the one significant relationship.
In Ireland, a significant positive relationship was found between the existence of career pathing with days spent training by technical/skilled staff, level of specialization or generalization and formality of training. In other words, the higher the extent of career pathing, the higher the number of days spent in training by skilled/technical staff and the higher the level of formal training. Focus of training tended to be more generalized the higher the extent of existence of career pathing.

However, this situation is not indicative of the situation in the other countries examined. In Singapore, the only two training variables significantly related to career pathing were specialization/ generalization of training and formality of training. Hong Kong and China yielded the same results, which were are not unlike Singapore. The only significant relationship 
Aidan Kelly,

Teresa Brannick, John Hulpke,

Jacqueline Levine and

Michelle To

Linking organisational training and development practices

with new forms of career

structure: a cross-national

exploration

Journal of European Industrial

Training

27/2/3/4 [2003] 160-168 here was between career pathing and

formality of training. The higher the level of career pathing, the more formal the available training.

The multiple comparisons also lend support to the above, suggesting that Ireland differs from the Asian samples. The level of existence of career pathing in Ireland would appear to be significantly lower than the level in Hong Kong or China. In addition to this, Irish organizations seem to provide more varied training, such as training in anticipation of future tasks. This may also be indicative of a new form of career, where organizations need to train their staff in a wide range of skills rather than to train them for one specific job.

However, surprisingly, while Irish companies tended to be larger than the other countries, the number of days spent in training is actually lower. One possible explanation for this is that this study failed to discern a difference between companies who had newer career structures in place and those that merely engage in "bad" human resource practices. It would follow that companies with less than satisfactory human resource practices would invest less time and capital in training their staff.

However, there is also another possibility. There may indeed be newer forms of careers in place in Irish organizations and it may be this that is measured by career pathing and not poor practices as suggested in the paragraph above. If this is the case then it is possible that the question used to measure amount of time in training failed to capture the full story. However, this is only a preliminary analysis of the data. Further analysis will hopefully enable us to unravel this conundrum. If newer forms of careers are in place in Ireland then we would expect employees to be taking more responsibility for their own training. Our findings also suggest that Irish employees get training from a variety of sources. A more in-depth analysis of the specific type of training engaged in by the four locations might give us a clearer picture of what is happening in terms of training and development. Clearly, more analysis is needed to clarify this issue.

\section{Conclusion}

In the standard human resource literature, high levels of career pathing are considered part of good modern practice. This consists of creating promotional opportunities and generally looking after all employees. This traditional way of conceptualising good practice would consider low levels of career pathing indicative of poor human resource practices in organizations. However, somewhat paradoxically, more recent literature relating to careers would indicate that lower levels of career pathing are indicative of the existence of newer models of careers.

The basic rationale behind this assumption is that the less clear career paths are within an organization, the less responsibility the organization is taking for its employees, thus fostering autonomy and self-management in its workers. Such organizations, according to the literature, are those within which a new order of career flourishes. One issue of concern here is whether these findings are indicative of a new model of careers, or whether they are symptomatic of bad practice, or how the new career distinguishes itself from "poor" human resource management. The disentanglement of this will be the focus of further analysis. However, one thing that is clear from the present research is that there seems to be great variations among cultures in terms of the types of careers enacted. This has wide implications in today's global economy where it is vital to appreciate that an understanding of culture is vital to successful management.

\section{References}

Allred, B.B., Snow, C.C. and Miles, R.E. (1996), "Characteristics of managerial careers in the 21st century", Academy of Management Executive, Vol. 10 No. 4, pp. 17-27.

Arthur, M. and Rousseau, D. (1996a), “A career lexicon for the 21st century", Academy of Management Executive, Vol. 10 No. 4, pp. 28-39.

Arthur, M. and Rousseau, D. (1996b), The Boundaryless Career: A New Employment Principle for a New Organisational Era, Oxford University Press, New York, NY.

Ashkenas, R., Ulrich, D., Jick, T. and Kerr, S. (2002), The Boundaryless Organization: Breaking the Chains of Organizational Structure, Jossey-Bass, San Francisco, CA.

Baruch, Y. (1999), "Integrated career systems for the 2000s", International Journal of Manpower, Vol. 20 No. 7, pp. 432-57.

Brousseau, K., Driver, M., Eneroth, K. and Larsson, R. (1996), "Career pandemonium: realigning organizations and individuals", The Academy of Management Executive, Vol. 10 No. 4, pp. 52-66.

Brown, D. (2002), "The role of work and cultural values in occupational choice, satisfaction, and success: a theoretical statement", Journal of Counseling and Development, Vol. 80 No. 1, pp. 48-56.

Cappelli, P. (1999), “Career jobs are dead”, California Management Review, Vol. 42 No. 1, pp. 146-67. 
Aidan Kelly,

Teresa Brannick, John Hulpke,

Jacqueline Levine and

Michelle To

Linking organisational training

and development practices

with new forms of career

structure: a cross-national

exploration

Journal of European Industrial

Training

$27 / 2 / 3 / 4$ [2003] 160-168
Cappelli, P. (2000), “A market-driven approach to retaining talent", Harvard Business Review, Vol. 78 No. 1, pp. 103-11.

Chow, I. (1995), “Career planning and development for Hong Kong Chinese managers", Journal of Asian Business, Vol. 11 No. 3.

Collin, A. and Young, R.A. (1986), "New directions for theories of career", Human Relations, Vol. 39 No. 9, pp. 837-54.

Granrose, C. (1995), “A model of organizational careers in national contexts", Journal of Asian Business, Vol. 11 No. 3.

Hall, D.T. (1996), "Protean careers of the 21st century", The Academy of Management Executive, Vol. 10 No. 4, pp. 8-16.

Hall, D.T. and Associates (1996), The Career is Dead, Long Live The Career: A Relational Approach to Careers, Jossey-Bass, San Francisco, CA.

Handy, C. (1997), “The search for meaning: a conversation with Charles Handy by Charles Handy", Leader to Leader, Summer, No. 5.

Jacoby, S.M. (1999a), “Are career jobs headed for extinction?", California Management Review, Vol. 42 No. 1, pp. 123-45.

Jacoby, S.M. (1999b), "Reply: premature reports of demise”, California Management Review, Vol. 42 No. 1, pp. 168-79.

Kao, C., Lee, T.Z. and Kuo, S. (1997), "Career paths in industrial management: a survey of Taiwan's manufacturing industries", Career Development International, Vol. 2 No. 4, pp. 189-94.

Kimeldorf, M. (1996), "Using job search portfolios in an uncertain labour market", Career Development International, Vol. 1 No. 5 , pp. 51-5.

Lawrence, A. (2002), "The lure of Shanghai: high tech's promised land", Topics (American Chamber of Commerce, Taipei), Vol. 31 No. 10, pp. 15-22.

Mallon, M. (1999a), “Going 'portfolio': making sense of changing careers", Career Development International, Vol. 4 No. 7, pp. 358-69.

Mallon, M. (1999b), "The transition from organisational employment to portfolio working: perceptions of 'boundarylessness', , Work Employment \& Society, Vol. 13 No. 2, pp. 329-53.

Manz, C., Keating, D. and Donnellon, A. (1990), "Preparing for an organisational change to employee self-management: the managerial transition”, Organisational Dynamics, Vol. 19, pp. 15-26.
Nicholson, N. (1996), "Career systems in crisis: change and opportunity in the information age", Academy of Management Executive, Vol. 10 No. 4, pp. 40-51.

Osterman, P. (1996), Broken Ladders: Managerial Careers in the New Economy, Oxford University Press, New York, NY.

Osterman, P. (2000), "Work reorganisation in an era of restructing: trends in diffusion and effects on employee welfare", Industrial \& Labor Relations Review, Vol. 53 No. 2, pp. 179-96.

Peiperl, M.A. and Baruch, Y. (1997), "Back to square zero: the post-corporate career", Organisational Dynamics, Spring, pp. 7-22.

Peng, T.-K. (1995), "Career planning and development of managers in Taiwan", Journal of Asian Business, Vol. 11 No. 3.

Quinn, J.B. (1999), "Strategic outsourcing: leveraging knowledge capabilities”, Sloan Management Review, Summer, pp. 9-21.

Rousseau, D.M. (1998), "Trust in organisations: frontiers of theory and research", Administrative Science Quarterly, Vol. 43 No. 1, pp. 186-8.

Rousseau, D.M. and Arthur, M. (1999), "The boundaryless human resource function: building agency and community in the new economic era", Organisational Dynamics, Spring, pp. 7-18.

Templer, A.J. and Cawsey, T.F. (1999), "Rethinking career development in an era of portfolio careers", Career Development International, Vol. 4 No. 2, pp. 70-6.

Von Hippel, C., Mangum, C., Greenberger, S.L., Heneman, D.B. and Skoglind, J.D. (1997), "Temporary employment: can organisations and employees both win?", Academy of Management Executive, Vol. 11 No. 1, pp. 93-104.

Watts, A.G. (1996), “Toward a policy for lifelong career development: a transatlantic perspective", The Career Development Quarterly, September, Vol. 45, pp. 41-53.

\section{Further reading}

Ta, T. (2001), "Human resources crucial: job hop, yes or no?”, Shanghai Star, 4 January, p. 10.

Taormina, R. (1998), "Employee attitudes toward organizational socialization in the People's Republic of China, Hong Kong, and Singapore", The Journal of Applied Behavioral Science, Vol. 34 No. 4, pp. 468-85. 